\title{
PENGARUH CAR, NPF, DAN FDR TERHADAP ROA BANK MEGA SYARI'AH PERIODE MARET 2007 - DESEMBER 2014
}

\author{
Ahmad Mudzakir \\ Fakultas Syari'ah dan Hukum UIN Sunan Gunung Djati Bandung \\ Jl. A. H. Nasution Nomor 105 Bandung \\ Email: mudzakir.ahmad@gmail.com
}

\begin{abstract}
Abstrak
Penelitian ini ditujukan untuk mengetahui pengaruh Capital Adequacy Ratio (CAR), Non Performing Financing (NPF), dan Financing to Defosit Ratio (FDR) terhadap Return On Asset (ROA) baik secara parsial maupun simultan pada Bank Mega Syariah. Populasi dalam penelitian ini adalah rasio keuangan Bank Mega Syariah. Data sampel adalah rasio CAR, NPF, FDR, dan ROA yang diambil dari laporan keuangan triwulanan yang dipublikasikan pada situs resmi Otoritas Jasa Keuangan periode Maret 2007 sampai Desember 2014. Penelitian ini menggunakan metode deskriptif dan verifikatif. Teknik analisis menggunakan regresi linear berganda dengan terlebih dahulu melakukan uji asumsi klasik seperti uji normalitas, heteroskedastisitas, multikolinearitas dan autokorelasi. Hasil penelitian menunjukan bahwa secara parsial CAR berpengaruh negatif dan signifikan terhadap ROA, NPF berpengaruh negatif tapi tidak signifikan terhadap ROA, sementara FDR berpengaruh positif tapi tidak signifikan terhadap ROA. Secara simultan CAR, NPF dan FDR berpengaruh signifikan terhadap ROA.
\end{abstract}

\section{Kata Kunci:}

CAR, FDR, NPF, dan ROA

\section{A. Pendahuluan}

Ekonomi dewasa ini sangat membutuhkan peranan yang besar dari industri perbankan, dimana perbankan bisa menggerakan ekonomi suatu negara, dengan kata lain bank yang merupakan bagian dari sistem perbankan bisa disebut sebagai salah satu motor penggerak ekonomi suatu negara. Hal tersebut dapat dilihat dari salah satu fungsi bank sebagai lembaga intermediasi pihak surplus dana dengan pihak depisit 
dana. ${ }^{1}$ Dimana bank dapat menghimpun dana dari pihak surplus dana kemudian menyalurkannya kepada pihak yang defisit dana untuk digunakan baik untuk konsumsi maupun untuk modal usaha yang bisa membuat roda ekonomi bergerak. Jika fungsi bank tersebut berjalan dengan baik maka perputaran dana akan terjadi dengan baik pula sehingga kegiatan ekonomi dimasyarakat bisa berjalan dengan lancar dan berkelanjutan, tetapi hal sebaliknya akan terjadi jika fungsi intermediasi bank tersebut terhambat atau bahkan tidak berjalan dengan lancar.

Bank adalah badan usaha yang menghimpun dana dari masyarakat dalam bentuk simpanan dan menyalurkannya kepada masyarakat dalam bentuk kredit dan atau bentuk-bentuk lainnya dalam rangka meningkatkan taraf hidup masyarakat banyak (UU No. 10 Tahun 1998). Berdasarkan jenisnya bank dapat dikelompokan menjadi dua yakni ; Bank Umum dan Bank Perkreditan Rakyat. Menurut Undang - undang No. 10 Tahun 1998 bank umum adalah bank yang melaksanakan kegiatan usaha secara konvensional dan atau berdasarkan prinsip syari'ah yang dalam kegiatannya memberikan jasa dalam lalu lintas pembayaran. Sementara Bank Perkreditan Rakyat adalah bank yang melaksanakan kegiatan usaha secara konvensional atau berdasarkan prinsip syari'ah yang dalam kegiatannya tidak memberikan jasa dalam lalu lintas pembayaran. Sementara bank berdasarkan pembayaran bunga atau pembagian hasil usaha dapat dibedakan menjadi dua yaitu bank konvensional dan bank syari'ah. ${ }^{2}$

Perbankan syari'ah didirikan sebagai upaya kaum muslimin untuk mendasarkan segenap aspek kehidupan ekonominya berlandaskan alQur'an dan al-Sunnah ${ }^{3}$ Dengan begitu semakin besar keinginan masyarakat untuk mendasarkan kehidupan ekonominya yang berlandaskan Al-Qur'an dan As-Sunnah maka besar kemungkinan akan semakin pesat pula perkembangan bank syari'ah di Indonesia khususnya. Hal tersebut terbukti dengan data dari Statistik Perbankan Syari'ah yang dikeluarkan oleh Otoritas Jasa Keuangan per Januari 2015, dimana jumlah bank umum syari'ah meningkat dari 6 bank pada tahun 2009 menjadi 12 bank pada tahun 2014. Begitu juga dengan bank pembiayaan syari'ah

1 Veithzal Rifai, Bank and Financial Institution Management Conventional \& Sharia System (Jakarta: PT. Raja Grafindo Persada. 2007), hlm. 109. Edisi kedua.

2 Lukman Dendawijaya, Manajemen Perbankan (Bogor: Ghalia Indonesia. 2009),

3 Muhammad Syafi'i Antonio, Bank Syariah dari Teori ke Praktek (Depok: Gema Insani. 2001), hlm. 18. 
yang pada tahun 2009 tercatat hanya 138 bank, tapi pada tahun 2014 jumlahnya meningkat menjadi 163 bank. Bukti lain pesatnya perkembangan perbankan syari'ah dapat dilihat dari terus meningkatnya aset yang dimiliki oleh perbankan syari'ah, dimana dengan sumber data yang sama tercatat bahwa aset perbankan syari'ah tahun 2009 hanya sebesar Rp 66,909 triliun sementara pada tahun 2014 meningkat signifikan menjadi Rp 272,343 triliun. Pesatnya perkembangan perbankan syari'ah harus diimbangi dengan kinerja yang semakin hari semakin menjanjikan kepuasan nasabah. Hal tersebut dikarenakan bank merupakan lembaga yang beroperasi berdasarkan kepercayaan, dengan kata lain kepercayaan masyarakat berbanding lurus dengan kesuksesan usaha bank itu sendiri, semakin tinggi kepercayaan masyarakat terhadap bank maka semakin sukses bank dalam menjalankan bisnisnya, dan begitu juga sebaliknya. Kinerja bank memiliki beberapa indikator, diantaranya permodalan, likuiditas dan profiitabilitas, dimana ketiga indikator tersebut menjadi acuan penilaian para nasabah untuk memberikan kepercayaannya kepada bank yang bersangkutan.

Pentingnya indikator - indikator kinerja bank tersebut mendorong para peneliti untuk mengembangkan teori atau bahkan menemukan teori baru mengenai hal tersebut, baik itu penelitian mengenai satu indikator maupun keterhubungan antar indikator serta keberpengaruhan satu indikator dengan indikator lainnya. Penelitian mengenai pengaruh satu dan atau dua variabel terhadap variabel lainnya dalam rasio kinerja bank telah banyak dilakukan dan tidak jarang terjadi perbedaan hasil penelitian dengan kata lain tidak jarang terjadi research gap. Berikut beberapa hasil penelitian mengenai indikator atau variabel kinerja bank:

Tabel. 1

Penelitian Terdahulu

\begin{tabular}{|c|c|c|c|}
\hline No & Penulis & Judul & Hasil Penelitian \\
\hline 1 & $\begin{array}{l}\text { Dwi Ervina } \\
\text { Rahmawati (2011) }\end{array}$ & $\begin{array}{l}\text { Pengaruh Tingkat } \\
\text { Kecukupan Modal, } \\
\text { Kualitas Aktiva } \\
\text { Produktif, dan Tingkat } \\
\text { Likuiditas Terhadap } \\
\text { Tingkat Profitabiliats } \\
\text { Perbankan Umum } \\
\text { Syariah. }\end{array}$ & $\begin{array}{ll}\text { 1. } & \text { Secara parsial kecukupan } \\
\text { modal (CAR) dan rasio } \\
\text { kualitas aktiva produktif } \\
\text { (PPAP) berpengaruh positif } \\
\text { dan signifikan terhadap } \\
\text { profitabilitas (ROA). } \\
\text { Sedangkan rasio likuiditas } \\
\text { (LDR) berpengaruh negatif } \\
\text { dan signifikan terhadap } \\
\text { profitabilitas (ROA). }\end{array}$ \\
\hline
\end{tabular}




\begin{tabular}{|c|c|c|c|}
\hline & & & $\begin{array}{l}\text { 2. } \\
\text { Secara simultan variabel } \\
\text { kecukupan modal (CAR), } \\
\text { Kualitas Aktiva Produktif } \\
\text { (PPAP), dan likuiditas (LDR) } \\
\text { berpengaruh signifikan } \\
\text { terhadap profitabiitas } \\
\text { (ROA). }\end{array}$ \\
\hline 2 & $\begin{array}{l}\text { Rina Ayu Ida } \\
\text { Mawarni (2012) }\end{array}$ & $\begin{array}{l}\text { Pengaruh Tingkat } \\
\text { Risiko Pembiayaan, } \\
\text { Likuiditas, dan Tingkat } \\
\text { Kecukupan Modal } \\
\text { Terhadap } \\
\text { Profitabilitas PT.Bank } \\
\text { Muamalat Indonesia } \\
\text { Periode 2006-2014 }\end{array}$ & 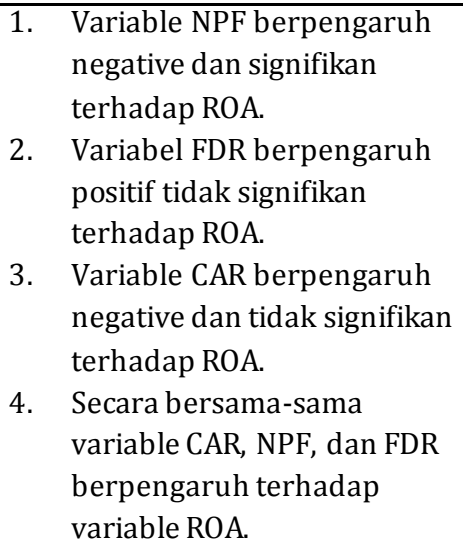 \\
\hline 3 & $\begin{array}{l}\text { Linda } \\
\text { Widyaningrum } \\
(2015)\end{array}$ & & $\begin{array}{ll}\text { 1. } & \text { Secara simultan CAR, NPF, } \\
\text { FDR, OER berpengaruh } \\
\text { signifikan terhadap ROA. } \\
\text { 2. Secara parsial CAR, FDR, } \\
\text { NPF tidak berpengaruh } \\
\text { signifikan terhadap ROA, } \\
\text { namun OER berpengaruh } \\
\text { signifikan terhadap ROA }\end{array}$ \\
\hline 4 & $\begin{array}{l}\text { M. Shalahuddin } \\
\text { Fahmi (2013) }\end{array}$ & $\begin{array}{l}\text { Pengaruh CAR, NPF, } \\
\text { FDR dan BOPO } \\
\text { terhadap Profitabilitas } \\
\text { Bank Umum Syariah. }\end{array}$ & 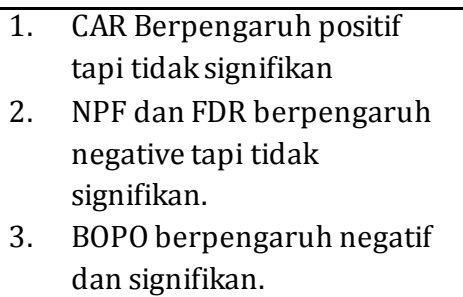 \\
\hline
\end{tabular}

Berdasar tabel di atas jelas terjadi research gap sebagai berikut :

1. Menurut Dwi Ervina CAR berpengaruh positif dan signifikan terhadap ROA, sementara menurut M Shalahuddin Fahmi CAR berpengaruh positif tapi tidak signifikan terhadap ROA. Pendapat yang bertolak belakang disampaikan oleh Rina Ayu Ida yang penelitiannya menyimpulkan bahwa CAR berpengaruh negatif dan tidak signifikan terhadap ROA. 
2. Menurut Rina Ayu Ida NPF berpengaruh negtaif dan signifikan terhadap ROA, sementara Linda Widyaningrum tidak berpengaruh signifikan terhadap ROA dan M Shalahuddin Fahmi berpendapat NPF berpengaruh negatif tapi tidak signifikan.

3. Menurut Dwi Ervina LDR/FDR berpengaruh negatif terhadap ROA, sementa Rina Ayu Ida berpendapat bahwa FDR berpengaruh positif terhadap ROA.

Selain research gap di atas fakta dilapangan menunjukan ada ketidak konsistenan pengaruh antar indikator kinerja bank seperti tertera pada tabel 2 berikut ini:

Tabel 2

Data CAR, NPF, FDR dan ROA Bank Mega Syariah

\begin{tabular}{|c|c|c|c|c|c|}
\hline NO & Periode & CAR & NPF & FDR & ROA \\
\hline 1 & Maret 2007 & 9,32 & 1,9 & 54,6 & 5,43 \\
\hline 2 & Juni 2007 & 10,72 & 1,1 & 71,44 & 5,37 \\
\hline 3 & September 2007 & 11,58 & 1,19 & 73,36 & 5,59 \\
\hline
\end{tabular}

Sumber : situs OtoritasJasa Keuangan

Pada tabel diatas terdapat ketidak konsistenan pengaruh CAR terhadap ROA, dimana pada periode Maret dan Juni ketika CAR naik dari 9,32\% menjadi $10,72 \%$ dan ROA turun dari 5,43\% menjadi 5,37\% ini berarti CAR berpengaruh negatif terhadap ROA. Tetapi pada periode berikutnya Juni dan September CAR berpengaruh positif terhadap ROA dimana CAR naik dari $10,72 \%$ menjadi $11,58 \%$ begitu juga ROA naik dari 5,37\% menjadi 5,59\%. Begitu pula dengan data NPF yang sama tidak konsisten, dimana periode Maret dan Juni ada penurunan dari 1,9\% menjadi $1,1 \%$ dan ROA mengalami penurunan juga dari $5,43 \%$ menjadi 5,37\% ini berarti ada pengaruh positif antara NPF dengan ROA, namun secara teori NPF berpengaruh negatif terhadap ROA. Pada FDR terjadi kenaikan dari $54,6 \%$ pada Maret menjadi $71,4 \%$ pada Juni sementara ROA turun 5,43\% mejadi 5,37\% sehingga sepintas dapat disimpulkan bahwa FDR berpengaruh negatif terhadap ROA sementara periode berikutnya terjadi sebaliknya FDR berpengaruh positif terhadap ROA, dimana FDR naik dari $71,44 \%$ menjadi $73,36 \%$ begitu pula ROA naik dari 5,37\% menjadi 5,59.

Berdasarkan research gap dan kedidak konsistenan fakta dilapangan mengenai data pengaruh CAR, NPF, dan FDR terhadap ROA di atas maka penulis tertarik untuk melakukan penelitian lebih lanjut 
berkenaan dengan pengaruh CAR, NPF dan FDR terhadap ROA dengan objek penelitian di Bank Mega Syariah.

\section{B. Kajian Literatur}

a. Capital Adequacy Ratio (CAR).

Analisis solvabilitas adalah analisis untuk mengukur kemampuan bank dalam memenuhi kewajiban jangka panjangnya atau kemampuan bank untuk memenuhi kewajiban-kewajiban jika terjadi likuidasi bank. ${ }^{4}$ CAR merupakan salah satu rasio solvabilitas yang mencerminkan seberapa jauh seluruh aktiva bank yang mengandung risiko ikut dibiayai dari dana modal sendiri. Dengan kata lain CAR adalah rasio kinerja bank untuk mengukur kecukupan modal untuk menunjang aktiva yang menghasilkan risiko seperti pembiayaan.

$$
C A R=\frac{\text { Modal Inti }+ \text { Pelengkap }}{A T M R} \times 100 \%
$$

b. Non Performing Financing (NPF)

Kualitas aktiva produktif merupakan tingkat kemampuan atau kualitas aktiva yang dapat menghasilkan pendapatan bagi bank. NPF merupakan salah satu indikator yang digunakan manajemen bank dalam mengukur kualitas aktiva produktif yang dimilikinya. Lebih rinci rasio ini digunakan untuk mengetahui pembiayaan bermasalah yang ditanggung oleh bank berdasarkan total pembiayaan yang disalurkan. Berdasarkan Surat Edaran Bank Indonesia Nomor 9/29/DPbs Tanggal 7 Desember 2007, NPF dapat dihitung dengan menggunakan rumus :

$$
N P F=\frac{\text { Jumlah Pembiayaan Bermasalah }}{\text { Jumlah Pembiayaan }} \times 100 \%
$$

Non Performing Financing dalam penelitian ini dijadikan variable independen yang pertama, dimana datanya didapat dari laporan keuangan publikasi bank umum syariah triwulan periode Maret 2007 - Desember 2014. Skala pengukuran untuk NPF ini menggunakan skala rasio.

c. Financing to Deposit Ratio (FDR)

Likuiditas merupakan tingkat kemampu bayaran bank terhadap kewajiban jangka pendek yang dimilikinya. FDR merupakan salah

${ }^{4}$ Lukman Dendawijaya, Manajemen Perbankan (Bogor: Ghalia Indonesia. 2009), cet ke-2, hlm. 121. 
satu indikator yang digunakan manajemen bank dalam mengukur likuiditas bank. Lebih rinci FDR menghitung jumlah pembiayaan yang disalurkan dengan menggunakan dana pihak ketiga. FDR dapat dihitung dengan menggunakan rumus :

$$
F D R=\frac{\text { Jumlah Dana yang disalurkan }}{\text { Jumlah dana Pihak Ketiga }} \times 100 \%
$$

FDR dalam penelitian ini dijadikan variable independen yang kedua, dimana nilai FDR didapat dari laporan keuangan publikasi bank umum syariah triwulan pada periode Maret 2007 - Desember 2014 dengan skala pengukuran yang digunakan adalah skala rasio.

d. Return On Assets (ROA)

Profitabilitas merupakan tingkat kemampuan bank dalam menghasilkan laba. ROA adalah salah satu rasio yang digunakan oleh manajemen bank untuk mengetahui kemampuan bank dalam mengasilkan laba berdasarkan asset yang digunakannya. Berdasarkan peraturan Bank Indonesia Nomor 9/29/DPbs tanggal 7 Desember 2007, ROA dirumuskan sebagai berikut:

$$
R O A=\frac{\text { Laba Sebelum Pajak }}{\text { Rata }- \text { rata Total Aset }} \times 100 \%
$$

ROA pada penelitian ini dijadikan variabel dependen, dimana nilai ROA diperoleh dari laporan keuangan triwulan bank umum syariah periode Maret 2007 - Desember 2014 dalam skala pengukuran menggunakan skala rasio.

\section{Hubungan Antar Variabel/Kerangka Pemikiran}

CAR merupakan rasio kecukupan modal yang mencerminkan modal sendiri yang dimiliki oleh bank, dimana semakin tinggi modal sendiri yang dimiliki maka semakin besar kemungkinan aktiva produktif yang disalurkan dan semakin besar pula peluang mendapatkan laba dari aktiva produktif tersebut sehingga CAR dapat berpengaruh positif terhadap ROA. Hal tersebut menghasilkan hipotesis pertama yaitu : H1 : CAR berpengaruh positif terhadap ROA.

NPF merupakan rasio dari kualitas aktiva produktif yang mencerminkan pembiayaan yang bermasalah dari aktiva produktif tersebut. Semakin besar nilai NPF maka semakin jelek kualitas aktiva, jika kualitas aktiva semakin jelek berarti laba (ROA) semakin jelek pula, dengan kata lain NPF berhubungan negatif dengan ROA. Hal tersebut menghasilkan hipotesis kedua yaitu : 
H2 : NPF berpengaruh negative terhadap ROA.

FDR merupakan rasio likuiditas yang mencerminkan seluruh jumlah pembiayaan yang diberikan bank dengan dana yang diterima oleh bank.dendawijaya. Bila nilai FDR besar itu mencerminkan jumlah pembiayaan yang diberikan besar dan akan berpengaruh kepada kemungkinan laba (ROA) yang dihasilkan besar pula. Dengan demikian FDR berpengaruh positif terhadap ROA. Hal tersebut menghasilkan hipotesis ketiga, yaitu :

H3 : FDR berpengaruh positif terhadap ROA

Dari ketiga hipotesis di atas, maka bisa diambil hipotesis yang keempat, yaitu : H4 : CAR, NPF, dan FDR berpengaruh terhadap ROA.

\section{Hipotesis}

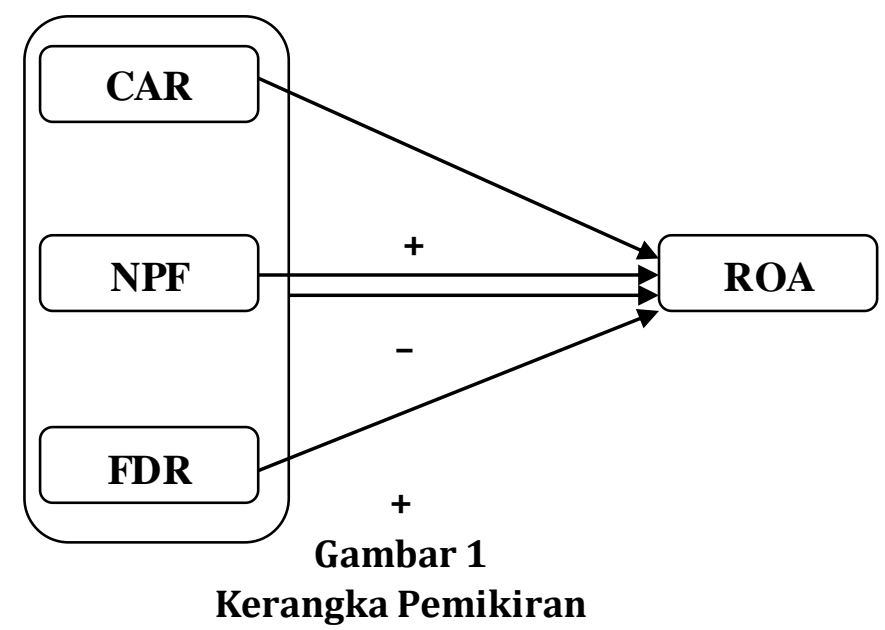

H1 : CAR berpengaruh positif terhadap ROA

H2 : NPF berpengaruh negatif terhadap ROA

H3 : FDR berpengaruh positif terhadap ROA

H4 : CAR, NPF dan FDR secara simultan berpengaruh terhadap ROA

\section{Pengujian Empiris dan Hasil}

\section{Uji Asumsi}

Penulis menggunakan analisis regresi dalam penelitian ini, sehingga data yang diolah harus memenuhi beberapa asumsi dalam analisis regresi, adapun asumsi yang harus dipenuhi dalam analisis regresi adalah :

1) Residual menyebar normal (asumsi normalitas);

2) Antar residual saling bebas (Autokorelasi); 
3) Kehomogenan ragam residual (Asumsi Heteroskedastisitas); dan

4) Antar variable independent tidak berkorelasi (multikolinearitas)..$^{5}$

\section{Uji Normalitas}

Uji normaltas berguna untuk menentukan data yang telah dikumpulkan berdistribusi normal atau diambil dari populasi normal. ${ }^{6}$ Dalam penelitian ini uji normalitas menggunakan uji kolmogorov smirnov. Tes normalitas data dilihat dari nilai signifikansi. Jika nilai sig lebih besar dari 5\% maka dapat disimpulkan bahwa residual menyebar tidak normal, dan jika sig lebih kecil dari 5\% maka dapat disimpulkan bahwa residual menyebar normal. ${ }^{7}$ Berikut ini tabel hasil uji normalitas:

Tabel 3

Uji Normalitas

One-Sample Kolmogorov-Smirnov Test

\begin{tabular}{|ll|l|}
\hline & & Unstandardized Residual \\
\hline $\mathrm{N}$ & & 32 \\
Normal Parametersa, & Mean &, 0000000 \\
& Std. Deviation & 1,26130155 \\
Most Extreme Differences & Absolute &, 113 \\
& Positive &, 053 \\
& Negative &,- 113 \\
Test Statistic & &, 113 \\
Asymp. Sig. (2-tailed) & &, $200^{c, d}$ \\
\hline
\end{tabular}

a. Test distribution is Normal.

b. Calculated from data.

c. Lilliefors Significance Correction.

$\mathrm{d}$. This is a lower bound of the true significance.

Sumber : Output SPSS, data diolah 2016

Interpretasi :

Dari hasil output SPSS di atas tampak bahwa nilai signifikansi sebesar 0,20 lebih besar dari 0,05, sehingga dapat disimpulkan bahwa data penelitian ini berdistribusi normal.

\section{Uji Heteroskedastisitas}

Heteroskedastisitas adalah ketidaksamaan varian dari residual untuk semua pengamatan pada model regresi. ${ }^{8}$ Tujuan dari uji heteroskedastisitas adalah untuk mengetahui apakah ada ketidaksamaan atau

${ }^{5}$ Agus Tri Basuki dan Nano Prawoto, Analisis Regresi dalam Penelitian Ekonomi \& Bisnis (Jakarta: PT. Raja Grafindo Persada. 2016),cet. ke-1, hlm. 46.

${ }^{6}$ Ibid., hlm. 57.

${ }^{7}$ Ibid., hlm. 60.

8 Ibid., hlm. 63. 
ketidak seragaman residual pada pengamatan. Dalam penelitian ini uji heteroskedastisitas dilakukan dengan menggunakan uji Glejser. Tes Heteroskedastisitas data dilihat dari nilai signifikansi. Jika nilai sig lebih besar dari 5\% maka dapat disimpulkan bahwa tidak terjadi heteroskedastisitas, dan jika sig lebih kecil dari 5\% maka dapat disimpulkan bahwa terjadi heteroskedastisitas. Berikut ini hasil uji glejser yang dilakukan peneliti :

\section{Tabel 4}

Uji Heteroskedastisitas

Coefficients $^{a}$

\begin{tabular}{|c|c|c|c|c|c|c|}
\hline \multirow{2}{*}{\multicolumn{2}{|c|}{ Model }} & \multicolumn{2}{|c|}{$\begin{array}{l}\text { Unstandardized } \\
\text { Coefficients }\end{array}$} & \multirow{2}{*}{$\begin{array}{l}\text { Standardized } \\
\text { Coefficients } \\
\text { Beta }\end{array}$} & \multirow[b]{2}{*}{$\mathrm{t}$} & \multirow[b]{2}{*}{ Sig. } \\
\hline & & B & Std. Error & & & \\
\hline \multirow[t]{4}{*}{1} & (Constant) & ,977 & 1,110 & & ,880 & ,386 \\
\hline & CAR &,- 017 & ,048 &,- 057 &,- 357 & ,724 \\
\hline & NPF &,- 325 & 164 &,- 377 & $-1,988$ & ,057 \\
\hline & FDR & 016 & 014 & 223 & 1,173 &, 251 \\
\hline
\end{tabular}

a. Dependent Variable: RES2

Sumber : Output SPSS, data diolah 2016

Interpretasi :

Berdasarkan output di atas diketahui bahwa nilai signifikansi variabel CAR (X1) sebesar 0,724 lebih besar dari 0,05 yang berarti tidak terjadi heterokedastisitas pada variabel CAR. Nilai signifikansi variabel NPF (X2) sebesar 0,057 lebih besar dari 0,05 yang berarti tidak terjadi heteroskedastsitas pada variabel NPF (X2). Nilai signifikansi variabel FDR (X3) sebesar 0,251 lebih besar dari 0,05 yang berarti tidak terjadi heteroskedastisitas. Kesimpulan untuk uji heterokedastisitas adalah tidak terjadi heteroskedastisitas data pada variabel yang akan diuji dengan kata lain data yang akan diuji homogen.

\section{Uji Multikolonieritas}

Multikolonieritas adalah adanya hubungan linear antara peubah bebas X dalam model regresi ganda. ${ }^{9}$ Karena penelitian ini bertujuan mengkaji hubungan antara peubah bebas dengan peubah respon yang menuntut tidak terjadinya multikolinearitas, maka perlu diuji apakah model regresi yang diteliti terbebas dari multikolinearitas atau tidak. Penilaian multikolinearitas dapat dilihat dari nilai varian Inflation factor (VIF). Jika nilai VIF < 10 maka tidak terjadi multikolinearitas antar 
variable independen. ${ }^{10}$ Berikut ini hasil uji multikolinearitas menggunakan SPSS :

Tabel 5

Uji Multikolinearitas

Coefficients ${ }^{a}$

\begin{tabular}{|c|c|c|c|c|c|c|c|}
\hline \multirow[b]{2}{*}{ Model } & \multicolumn{2}{|c|}{$\begin{array}{l}\text { Unstandardized } \\
\text { Coefficients }\end{array}$} & \multirow{2}{*}{\begin{tabular}{|c|}
$\begin{array}{c}\text { Standardiz } \\
\text { ed } \\
\text { Coefficient } \\
\text { s }\end{array}$ \\
Beta \\
\end{tabular}} & \multirow[b]{2}{*}{$\mathrm{t}$} & \multirow[b]{2}{*}{ Sig. } & \multicolumn{2}{|c|}{$\begin{array}{l}\text { Collinearity } \\
\text { Statistics }\end{array}$} \\
\hline & B & $\begin{array}{l}\text { Std. } \\
\text { Error }\end{array}$ & & & & $\begin{array}{c}\text { Toleran } \\
\text { ce }\end{array}$ & VIF \\
\hline $\begin{array}{ll}1 & \text { (Consta } \\
& \text { nt) }\end{array}$ & 4,918 & 2,468 & & 1,993 & 056 & & \\
\hline CAR &,- 276 & 107, &,- 408 & $-2,592$ & 015, & 999 & 1,001 \\
\hline NPF &,- 333 & 364 & -172 &,- 914 & 368 & 704 & 1,419 \\
\hline FDR & 039, & 031 & 237 & 1,266 & 216 & 705 & 1,419 \\
\hline
\end{tabular}

a. Dependent Variable: ROA

Sumber : Output SPSS, data diolah 2016

Interpretasi :

Berdasarkan output SPSS di atas, nilai tolerance variabel CAR sebesar 0,999, NPF sebesar 0,704 dan FDR sebesar 0,705 yang semuanya bernilai lebih besar dari 0,10. Sementara itu, nilai VIF variabel CAR sebesar 1,001, NPF sebesar 1,419 dan FDR sebesar 1,419 yang semuanya lebih kecil dari 10,00, maka dapat disimpulkan bahwa tidak terjadi multikolinearitas.

\section{Uji Autokorelasi}

Uji autokorelasi digunakan untuk mengetahuiada atau tidaknya penyimpangan korelasi yang terjadi antara residual satu pengamatan dengan pengamatan lain pada model regresi.tri. Jika DW terletak diantara du dan 4 - du maka tidak terjadi autokorelasi dan jika DW terletak antara dl dan du maka hasil tidak pasti .Berikut hasil olah data uji autokorelasi yang menggunakan uji durbin Watson :

\section{Tabel 6}

\section{Uji Autokorelasi}

Model Summaryb

\begin{tabular}{|l|l|l|c|c|c|}
\hline Model & $\mathrm{R}$ & R Square & $\begin{array}{c}\text { Adjusted R } \\
\text { Square }\end{array}$ & $\begin{array}{c}\text { Std. Error of } \\
\text { the Estimate }\end{array}$ & Durbin-Watson \\
\hline
\end{tabular}

10 Ibid., hlm. 62 . 


\begin{tabular}{|l|l|l|l|l|r|}
\hline 1 &, $922^{\mathrm{a}}$ &, 851 &, 828 &, 60201 & 1,471 \\
\hline
\end{tabular}

Interpretasi:

Merujuk pada output SPSS nilai dw adalah 1,471, sementara nilai dl dan du adalah 1,2437 dan 1,6505, maka dapat disimpulkan bahwa dw berada diantara dl dan du sehingga tidak ada kesimpulan yang pasti.

Karena 3 asumsi terpenuhi dan 1 asumsi tidak pasti maka peneliti menarik kesimpulan bahwa data yang digunakan telah memenuhi asumsi analisis regresi.

Statistik Deskriptif

Tabel 7

Hasil Analisis Deskriptif Data

\begin{tabular}{|l|l|l|l|}
\hline Variabel & Mean & Standar Deviasi & N \\
\hline CAR & 13,42 & 2,24 & 32 \\
\hline NPF & 1,66 & 0,78 & 32 \\
\hline FDR & 52,26 & 9,28 & 32 \\
\hline ROA & 2,68 & 1,51 & 32 \\
\hline
\end{tabular}

Sumber : output SPSS, data diolah 2016

Interpretasi:

Pada periode Maret 2007 - Desember 2014 CAR Bank Mega Syariah rata-rata sebesar $13,42 \%$ dengan standar deviasi sebesar 2,24\%. NPF Bank Mega Syariah memiliki rata-rata 1,66\% dengan stadar deviasi 0,78. FDR dengan rata-rata 52,26\% dan standar deviasi 9,28. ROA rata - rata sebesar 2,68\% dengan standar deviasi 1,51\%.

\section{Uji Regresi}

\section{Tabel 8}

\section{Uji Regresi}

\section{Coefficients $^{\mathrm{a}}$}

\begin{tabular}{|c|c|c|c|c|c|c|}
\hline \multirow{2}{*}{\multicolumn{2}{|c|}{ Model }} & \multicolumn{2}{|c|}{$\begin{array}{c}\text { Unstandardized } \\
\text { Coefficients }\end{array}$} & \multirow{2}{*}{$\begin{array}{c}\text { Standardized } \\
\text { Coefficients }\end{array}$} & \multirow[b]{2}{*}{$\mathrm{t}$} & \multirow[b]{2}{*}{ Sig. } \\
\hline & & B & Std. Error & & & \\
\hline \multirow[t]{4}{*}{1} & (Constant) & 4,918 & 2,468 & & 1,993 & ,056 \\
\hline & CAR &,- 276 & 107 &,- 408 & $-2,592$ & ,015 \\
\hline & NPF &,- 333 & ,364 & -172 &,- 914 & 368 \\
\hline & FDR & ,039 & ,031 & 237 & 1,266 & ,216 \\
\hline
\end{tabular}

a. Dependent Variable: ROA

Sumber : Output SPSS, data diolah 2016

Berdasarkan tabel hasil olah data melalui program SPSS diatas dapat diperoleh rumus regresi sebagai berikut : 
$\mathrm{Y}=4,918-0,276 \mathrm{X} 1-0,333 \mathrm{X} 2+0,039 \mathrm{X} 3+\mathrm{e}$

Interpretasi dari regresi diatas adalah sebagai berikut :

1. Konstanta (a)

Besar konstanta 4,918, ini berarti bahwa jika semua variabel bebas memiliki nilai 0 , maka nilai variabel terikat (Y) sebesar 4,918.

2. CAR (X1)

Nilai koefisien CAR (X1) sebesar - 0,276. Hal ini mengandung arti bahwa variabel CAR memiliki pengaruh negative terhadap ROA sehingga setiap kenaikan satu satuan variabel CAR, maka variable $Y$ akan turun sebesar 0,276 dengan asumsi bahwa variabel bebas yang lain dari model regresi adalah tetap.

3. $\mathrm{NPF}(\mathrm{X} 2)$

Nilai koefisien NPF (X2) sebesar - 0,333. Hal ini mengandung arti bahwa variabel NPF memiliki pengaruh negative terhadap ROA sehingga setiap kenaikan satu satuan variabel NPF, maka variabel ROA akan turun sebesar 0,333 dengan asumsi bahwa variabel bebas yang lain dari model regresi adalah tetap.

4. FDR (X3)

Nilai koefisien FDR (X3) sebesar 0,039. Hal ini mengandung arti bahwa variabel FDR memiliki pengaruh positif tehadap ROA, sehingga setiap kenaikan satu satuan variabel FDR maka variabel ROA akan naik sebesar 0,039.

\section{Uji F}

Uji $\mathrm{F}$ adalah uji analisis untuk menguji pengaruh secara simultan atau bersama-sama setaip variabel independen terhadap variabel dependen. Berikut table hasil uji F :

Tabel 9

Uji F

ANOVA $^{\mathrm{a}}$

\begin{tabular}{|c|c|c|c|c|c|c|}
\hline \multicolumn{2}{|c|}{ Model } & $\begin{array}{l}\text { Sum of } \\
\text { Squares }\end{array}$ & $\mathrm{df}$ & Mean Square & $\mathrm{F}$ & Sig. \\
\hline \multirow[t]{3}{*}{1} & Regression & 21,712 & 3 & 7,237 & 4,109 &, $016^{\mathrm{b}}$ \\
\hline & Residual & 49,317 & 28 & 1,761 & & \\
\hline & Total & 71,030 & 31 & & & \\
\hline
\end{tabular}

a. Dependent Variable: ROA

b. Predictors: (Constant), FDR, CAR, NPF

Sumber : Output SPSS, data diolah 2016

Uji statistik : 
Ho : $\beta_{1}=\beta_{2}=\beta_{3}=0$ secara bersama-sama tidak ada pengaruh antara CAR, NPF, dan FDR terhadap ROA

Ha : $\beta \neq \beta_{2} \neq \beta_{3} \neq 0$ secara bersama-sama ada pengaruh antara CAR, NPF, dan FDR terhadap ROA

Dari tabel diatas dihasilkan $\beta \neq \beta_{2} \neq \beta_{3} \neq 0$ berarti terima Ha dalam artian ada pengaruh secara simultan antara CAR, NPF, dan FDR terhadap ROA.

Kriteria pengujian signifikansi yaitu terima Ho jika F-hitung $\leq$ F-tabel dan tolak Ho jika F-hitung $\geq$ F-tabel

Dari output SPSS diatas didapat nilai F hitung sebesar 4,109 dengan nilai probabilitas (sig) sebesar 0,016. Nilai F hitung 4,109>2,93 F-tabel dan nilai sig. $0.016<0,05$; maka Ho ditolak dan Ha diterima. Kesimpulan secara simultan CAR, NPF, dan FDR berpengaruh signifikan terhadap ROA.

\section{Uji t}

Uji t adalah analisis yang ditujukan untuk mengetahui pengaruh individual setiap variabel independen terhadap variabel dependen. Berikut table hasil uji t:

\section{Tabel 10}

Uji t

\section{Coefficients $^{\mathrm{a}}$}

\begin{tabular}{|c|c|c|c|c|c|c|c|}
\hline \multirow[b]{2}{*}{ Model } & \multicolumn{2}{|c|}{$\begin{array}{l}\text { Unstandardized } \\
\text { Coefficients }\end{array}$} & \multirow{2}{*}{$\begin{array}{c}\begin{array}{c}\text { Standardiz } \\
\text { ed } \\
\text { Coefficient } \\
\mathrm{s}\end{array} \\
\\
\text { Beta } \\
\end{array}$} & \multirow[b]{2}{*}{$\mathrm{t}$} & \multirow[b]{2}{*}{ Sig. } & \multicolumn{2}{|c|}{$\begin{array}{c}\text { Collinearity } \\
\text { Statistics }\end{array}$} \\
\hline & B & $\begin{array}{l}\text { Std. } \\
\text { Error }\end{array}$ & & & & $\begin{array}{c}\text { Toleran } \\
\text { ce }\end{array}$ & VIF \\
\hline $\begin{array}{ll}1 & \text { (Consta } \\
& \mathrm{nt})\end{array}$ & 4,918 & 2,468 & & 1,993 & 056 & & \\
\hline CAR & -,276 & 107, &,- 408 & $-2,592$ & 015, & 999 & 1,001 \\
\hline NPF & -333 & 364 &,- 172 &,- 914 & 368 & ,704 & 1,419 \\
\hline FDR & 039, & 031 & ,237 & 1,266 & 216 & 705 & 1,419 \\
\hline
\end{tabular}

a. Dependent Variable: ROA

Uji statistik

Ho : $\beta_{1}=0$ tidak ada pengaruh CAR terhadap ROA

Ha : $\beta_{1} \neq 0$ ada pengaruh CAR terhadap ROA

Ho : $\beta_{2}=0$ tidak ada pengaruh NPF terhadap ROA 
Ha: $\beta_{2} \neq 0$ ada pengaruh NPF terhadap ROA

Ho : $\beta_{3}=0$ tidak ada pengaruh FDR terhadap ROA

Ho : $\beta_{3} \neq 0$ ada pengaruh FDR terhadap ROA

Dari output terlihat bahwa tampak bahwa : $\beta_{1} \neq \beta_{2} \neq \beta_{3} \neq 0$, maka keputusannya terima Ha atau ada pengaruh antara CAR terhadap ROA, NPF terhadap ROA, dan FDR terhadap ROA.

Kriteria pengujian signifikansi yaitu jika $-\mathrm{t}_{\text {tabel }} \leq \mathrm{t}_{\text {hitung }} \leq+\mathrm{t}_{\text {tabel }}$ maka terima Ho dan tolak Ha.

$\mathrm{t}_{\text {tabel }}=2,048$

$\mathrm{t}_{\text {hitung }}$ CAR : $-2,592 \rightarrow-2,048>-2,592<2,048$ berarti tolak Ho dan terima Ha dengan kata lain pengaruh CAR signifikan terhadap ROA $\mathrm{t}_{\text {hitung }} \mathrm{NPF}:-0,19 \rightarrow-2,048<-0,19<2,048$ berarti terima Ho dan tolak Ha dengan kata lain pengaruh NPF tidak signifikan terhadap ROA.

$\mathrm{t}_{\text {hitung }}$ FDR : 1,266 $\rightarrow-2,048<1,266<2,048$ berarti terima Ho dan tolak Ha dengan kata lain pengaruh FDR tidak signifikan terhadap ROA.

\section{Koefisien Determinasi}

Tabel 11

Model Summary ${ }^{b}$

\begin{tabular}{|l|r|r|r|c|}
\hline Model & $\mathrm{R}$ & R Square & \multicolumn{1}{|c|}{$\begin{array}{c}\text { Adjusted R } \\
\text { Square }\end{array}$} & $\begin{array}{c}\text { Std. Error of the } \\
\text { Estimate }\end{array}$ \\
\hline 1 &, $553^{\mathrm{a}}$ &, 306 &, 231 & 1,32715 \\
\hline
\end{tabular}

a. Predictors: (Constant), FDR, CAR, NPF

b. Dependent Variable: ROA

Sumber : Output SPSS, data diolah 2016

Dari output SPSS diatas didapat nilai Adjusted $R$ Square $\left(R^{2}\right)$ sebesar 0,231 atau 23,1\%. Hal tersebut menunjukan bahwa pengaruh variabel CAR, NPF dan FDR terhadap ROA oleh model persamaan regresi ini adalah sebesar 23,1\%, sementara sisanya sebesar 76,9\% dipengaruhi oleh factor-faktor lain yang tidak dimasukan dalam model regresi.

\section{E. Penutup}

Berdasarkan pemaparan di atas, dapat ditarik kesimpulan sebagai berikut:

1. CAR bepengaruh negatif dan signifikan terhadap ROA; 
2. NPF berpengaruh negatif tidak signifikan terhadap ROA;

3. FDR berpengaruh positif tidak signifikan terhadap ROA; dan

4. Secara simultan CAR, NPF, FDR berpengaruh signifikan terhadap ROA.

CAR berpengaruh negatif dan signifikan terhadap ROA, ini berarti semakin tinggi CAR maka akan berpengaruh terhadap semakin rendahnya ROA, dengan demikian manajemen bank hanya tinggal mengikuti aturan batas minimal CAR yang harus dikelola tidak meningkatkannya.

NPF merupakan indikator pengelolaan pembiayaan yang dilakukan oleh manajemen bank. Pada penelitian ini NPF berpengaruh negatif tapi tidak signifikan, ini berarti semakin tinggi nilai NPF maka akan berpengaruh terhadap semakin rendahnya ROA, dengan demikian manajemen Bank Mega Syariah dituntut untuk lebih hati-hati dalam pngelolaan pembiayaannya sehingga bisa menekan sekecil mungkin nilai NPF dengan mengurangi pembiayaan yang kurang lancar atau macet.

FDR berpengaruh positif tapi tidak signifikan, ini berarti semakin tinggi FDR maka akan berpengaruh terhadap semakin tinggi pula ROA yang dihasilkan, dengan demikian pihak manajemen minimal mengikuti himbauan Bank Indonesia yang mengharuskan FDR seharusnya di atas $80 \%$ serta tidak lebih dari $110 \%$.

\section{DAFTAR PUSTAKA}

Antonio, Muhammad Syafi'i. 2001. Bank Syariah dari Teori ke Praktek. Depok: Gema Insani Press.

Basuki, Agus Tri dan Prawoto, Nano. 2016. Analisis Regresi dalam Penelitian Ekonomi \& Bisnis. Jakarta: PT. Raja Grafindo Persada.

Dendawijaya, Lukman. 2009. Manajemen Perbankan. Bogor: Ghalia Indonesia.

Kusnendi. 2007. Model-Model Persamaan Struktural. Bandung: Alfabeta. Nazir, Moh. 1998. Metode Penelitian. Jakarta: Ghalia Indonesia.

Rivai, Veithzal. 2007. Bank and Financial Institution management conventional \& Sharia System. Jakarta: PT. Raja Grafindo Persada.

Sugiyono. 2005. Metode Penelitian Bisnis. Bandung: Alfabeta.

www.bi.go.id.

www.ojk.go.id. 